\title{
Tool Life of PM-HSS Cutting Tools when Milling of Titanium Alloy
}

Pavel Zeman ${ }^{1}$, Pavel Bach ${ }^{1}$, George Trmal ${ }^{2}$

${ }^{1}$ Research Centre of Manufacturing Technology, Czech Technical University in Prague, Horska 3, 128 00, Prague 2, Czech Republic, E-mail: p.zeman@rcmt.cvut.cz

${ }^{2} \mathrm{UWE}$, Bristol, UK.

Machining of titanium alloys meets with poor life of a cutting tool. It is caused by a low thermal conductivity and by a high strength-to-weight ratio of the alloys. Various approaches for cost-effective and productive machining titanium alloys are still researched. One of methods can be using the cutters made of modern high-speed steel (HSS) as a product of a powder metallurgy (PM) process. These materials (PM-HSS) possess better and homogenous mechanical properties than conventional high-speed steel. The PM-HSS cutters equipped with any effective coating allow increase cutting speed to the level which is typical for uncoated cemented carbide, while price of the tool is lower. In the article several PM-HSS cutting tool materials were compared to conventional cobalt based HSS from the tool life point of view. It was proved that conventional high-speed steel offers very long tool life and high tool performance at speed of $30 \mathrm{~m} / \mathrm{min}$. However the regular tooth pitch significantly decreases tool life for this cutting tool material. The main benefit of PM-HSS cutters can be fully utilized when cutting speed about 50 $\mathbf{m} / \mathbf{m i n}$ is applied. The cutters coated by effective thermal barrier showed longer tool life and higher performance of the cutting tools.

Keywords: titanium alloy; milling; high-speed steel; tool life

\section{Acknowledgement}

The paper has received funding from the Technology Agency of the Czech Republic (Project TE01020075). The authors would also like to thank the ZPS Frezovaci nastroje, Ltd. for support with supply of the tested tools and their reconditioning during the research.

\section{References}

[1] RIBEIRO, M. V., MOREIRA, M. R. V., FERREIRA, J. R. (2003). Optimization of titanium alloy (6Al-4V) machining. Journal of Materials Processing Technology. Vol. 143-144, pp. 458-463.

[2] EZUGWU, E. O., WANG, Z. M. (1997). Titanium alloys and their machinability - a review. Journal of Materials Processing Technology. Vol. 68, pp. 262-274.

[3] ARRAZOLA, P. J., GARAY, A., IRIARTE, L. M., ARMENDIA, M. (2008). Machinability of titanium alloys (Ti6Al4V and Ti555.3). Journal of Materials Processing Technology. Vol. 209, pp. 2223-2230.

[4] CHE-HARON, C. H. (2001). Tool life surface integrity in turning titanium alloy. Journal of Materials Processing Technology. Vol. 118, pp. 231-237.

[5] JAWAID, A., SHARIF, S., KOKSAL, S. (2000). Evaluation of wear mechanisms of coated carbide tools when face milling titanium alloy. Journal of Materials Processing Technology. Vol. 99, pp. 266-274.

[6] JIANXIN, D., YOUSHENG, L., WENLONG, S. (2008). Diffusion wear in dry cutting of Ti-6Al-4V with WC/Co carbide tools. Wear. Vol. 265, pp. 1776-1783.

[7] PARK, K.-H., et al. (2014). Eco-friendly Face milling of Titanium Alloy. International Journal of Precision Engineering and Manufacturing. Vol. 15, pp. 1159-1164.

[8] SU, Y., HE, N., LI, L., LI, X. L. (2006). An experimental investigation of effects of cooling/lubrication conditions on tool wear in high-speed end milling of Ti-6Al-4V. Wear. Vol. 261, pp. 760-766.

[9] NURUL AMIN, A. K. M., ISMAIL, A. F., NOR KHAIRUSSHIMA, M. K. (2007). Effectiveness of uncoated WC-Co and PCD inserts in end milling of titanium alloy - Ti-6Al-4V. Journal of Materials Processing Technology. Vol. 192-193, pp. 147-158.

[10] NORUTAKI, N., MURAKOSHI, A. (1983). Study on machining of titanium alloys. CIRP Annals. Vol. 32/1, pp. 65-69.

[11] CORDUAN, N. et al. (2003). Wear Mechanisms of New Tool Materials for Ti-6Al-4V High Performance Machining. CIRP Annals. Vol. 52/1, pp. 73-76. 
[12] EZUGWU, E. O., DA SILVA, R. B., BONNEY, J., MACHADO, A. R. (2005). Evaluation of the performance of $\mathrm{CBN}$ tools when turning Ti-6Al-4V alloy with high pressure coolant supplies. International Journal of Machine Tools and Manufacture. Vol. 45, pp. 1009-1014.

[13] NABHANI, F. (2001). Machining of aerospace titanium alloys. Robotics and Computer Integrated Manufacturing. Vol. 17, pp. 99-106.

[14] WANG, Z. G., RAHMAN, M., WONG, Y. S. (2005). Tool wear characteristics of binderless CBN tools used in high-speed milling of titanium alloys. Wear. Vol. 258, pp. 752-758.

[15] KUNDRAK, J., RACZKOVI, L., et. al.(2014). A Method for Planning the Cutting Ability of CBN Tools. Manufacturing Technology. Vol. 14, No. 2, pp. 206-213.

[16] ZOYA, Z. A., KRISHNAMURTHY, R. (2000). The performance of CBN tools in the machining of titanium alloys. Journal of Materials Processing Technology. Vol. 100, pp. 80-86.

[17] BYRNE, G., BIENIA, B. (1991). Tool life scatter when milling with TIN coated HSS indexible inserts. CIRP Annals. Vol. 40/1, pp. 45-48.

[18] BOUZAKIS, K.-D. et al. (1998). Experimental and FEM analysis of the fatigue behaviour of PVD coatings on HSS substrate in milling. CIRP Annals. Vol. 47/1, pp. 69-72

[19] BOUZAKIS, K.-D., et al. (2012). Cutting with coated tools: Coating technologies, characterization methods and performance optimization. CIRP Annals - Manufacturing Technology. Vol. 61, pp. 703-723.

[20] NORDIN, M., LARSSON, M., HOGMARK, S. (1999). Wear resistance of multi-layered PVD TiN/TaN on HSS. Surface and Coatings Technology. Vol. 120-121, pp. 528-534.

[21] SMITH, I. J., et al. (1997). Dry cutting performance of HSS twist drills coated with improved TiAlN. Surface and Coatings Technology. Vol. 90, pp. 164-171.

[22] CHEUNG, F. Y., ZHOU, Z. F., GEDDAM, A., LI, K. Y. (2008). Cutting edge preparation using magnetic polishing and its influence on the performance of high-speed steel drills. Journal of Materials Processing Technology. Vol. 208, pp. 196-204.

[23] RAMANATHAN, M. (2014). Performance of Tungstanium Carbide Coated PM HSS Tool in Machining Armour Steel. International Journal of Engineering and Technology. Vol. 3, pp. 175-178.।

[24] JAROS, A., SEDLAK, J., et. al.(2016). Investigation of the Influence of PVD Coatings Deposited on HSS Milling Cutter. Manufacturing Technology. Vol. 16, No. 2, pp. 506-512.

[25] RECH, J., YEN, Y. C., et. al. (2005). Tool wear characteristics of binderless CBN tools used in high-speed milling of titanium alloys. Wear. Vol. 259, pp. 1168-1176. 